\title{
What Motivates Czech Consumers to Buy Organic Food?*
}

\author{
JAN URBAN, IVA ZVĚřINOVÁ and MILAN ŠČASNÝ** \\ Charles University Environment Center, Prague
}

\begin{abstract}
The objective of this paper is twofold. First, the authors aim to analyse the factors that affect the intention of Czech consumers to purchase organic food using the theory of planned behaviour (TPB). Second, they employ an extended TPB model that introduces descriptive norms as an additional factor of behavioural intention. This study exploits data from a consumer survey of a sample of the Czech general adult population $(N=252)$ conducted in 2010. Structural equation modelling with an ML estimator is used to estimate model parameters. The empirical model derived from the TPB explains $44 \%$ of the variability of intention to purchase organic food. Descriptive norms are empirically distinct from injunctive norms and their inclusion in the model increases the explained variance of intention by an additional 5 percentage points. Attitudes and norms are the strongest predictors of the intention to purchase organic food, while perceived behavioural control has only a weak effect.
\end{abstract}

Keywords: theory of planned behaviour, organic food consumption, structural equation modelling, descriptive norms, Czech Republic

Sociologický časopis/Czech Sociological Review, 2012, Vol. 48, No. 3: 509-536

\section{Introduction}

Globally, the residential sector is mostly indirectly but sometimes even directly responsible for over $50 \%$ of all environmental impacts of human activity [Hertwich et al. 2010: 48-61]. In the Czech Republic, the residential sector accounts for $23 \%$ of the national consumption of raw materials and biomass and for $32 \%$ of the country's total emissions of greenhouse gasses [Kovanda and Hák 2012]. Most of the environmental impacts of the residential sector are attributable specifically to three consumption activities: transportation, energy consumption related to housing and food consumption. Out of these, food consumption is on average responsible for between $20 \%$ and $30 \%$ of residential impacts in most impact cat-

* This research was supported by the Czech Science Foundation (GAČR grant no. 403/08/1694) 'Application of the Model of Environmentally Significant Behaviour in the Czech Republic'. This support is gratefully acknowledged. We would like to thank Cliff McLenehan for proofreading the manuscript and two anonymous reviewers for their excellent comments, which helped us to improve the manuscript.

** Direct all correspondence to: Charles University Environment Center, José Martího 407/2, 162 00, Prague 6, e-mail: jan.urban@czp.cuni.cz.

C Sociologický ústav AV ČR, v.v.i., Praha 2012 
egories and as much as $60 \%$ in the category of eutrophication in EU25 countries [Tukker et al. 2006: 91-92]. Besides having a relatively large environmental effect, food consumption is also remarkable in that it can be changed in structure only to some degree, but cannot be avoided because nutrition is one of the basic human needs. A number of dietary curtailments have been proposed that could reduce the environmental burden of food consumption, including the substitution of conventional food with organic [Baroni et al. 2007; Jungbluth, Tietje and Scholz 2000].

Factors that influence consumers' choice of organic food are very complex and include motives related to social and environmental responsibility (environmental protection, animal welfare), as well as economic factors and barriers (organic price premium), factors related to one's well-being (health-, taste-, and quality-related preferences), and concerns for the well-being of family members [Boccaletti 2008]. This mixture of motives, particularly the need to weigh the social and environmental benefits of one's activity against other types of benefits and costs, are very typical of any pro-environmental behaviour.

The objective of this study is twofold. First, we want to explore the factors that affect the intention of Czech consumers to choose organic over conventional food. To this end, we make use of the theory of planned behaviour (TPB), which has proved to be very useful in guiding and unifying theoretically research on organic food consumption [Aertsens et al. 2009]. In particular, we explore the role of attitudes, subjective norms and perceived behavioural control as determinants of intention to consume organic food.

Second, and on a more theoretical level, we aim to apply an extended TPB model that introduces descriptive norms as an additional predictor of intention. This extended model has been proposed in the literature to account for the differences in the functioning of descriptive and injunctive norms. A focus on the role of normative factors in the TPB framework is particularly relevant in the context of organic food consumption, where the existence of social, environmental and altruistic motives leads to normative pressures on consumers.

As far as we are aware, this article is one of the few to test TPB in the context of organic food consumption in the Czech Republic and the first to examine the effects of descriptive norms on the intention to consume organic food.

\section{Organic food consumption in the Czech Republic}

The Czech organic market is characterised as an emerging market with relatively high annual growth (as much as $40 \%$ in 2008) but low market share (only $0.75 \%$ of total expenditures on food and beverages in 2009) [Václavík 2009]. Per capita expenditures on organic food in the Czech Republic were estimated to equal about $170 \mathrm{CzK}$ annually or 6.5 euros in 2008. These figures are very low in comparison with developed organic markets in places such as Denmark (139 euros), Switzer- 
land (133 euros), and Austria (104 euros), but similar to those in Estonia (9 euros), Croatia (8.3 euros), Portugal (7 euros) and Greece (5 euros) [BÖLW 2010].

Several empirical studies on organic food consumption in the Czech Republic have been published, all of which are based on cross-sectional data from consumer surveys. Unfortunately, only two of these studies use data representative of the Czech adult population [OECD 2011; Synergy Marketing and GfK 2006], three other studies exploit data representative of the Znojmo region and/or the capital city, Prague [Urban and Ščasný 2007; Urban, Ščasný and Zvěřinová 2008; Zvěřinová 2011]. Another study is based on a typological sample of a specific segment of the Czech population (people living in large towns, with secondary school or higher education, higher-than-average income, aged 16-50; see Ogilvy [2008]). The remaining studies [Živělová 2005, 2006; Živělová and Jánský 2006, 2007a, 2007b] are based on data coming from convenience samples, so generalisations of their results to any clearly defined population is very problematic. Only three of the Czech studies aim at an exploration of factors of the intention to consume organic food [Urban and Ščasný 2007; Urban, Ščasný and Zvěřinová 2008; Zvěřinová 2011], while the remaining studies are purely descriptive and mostly use only univariate statistics.

When asked to indicate associations that come to their mind when thinking about organic food, Czech consumers say that organic food is food without chemicals ( $31 \%$ of respondents), healthy food $(24 \%)$, environmentally friendly food (12\%), natural (11\%) and safe food (9\%) [Synergy Marketing and GfK 2006]. A higher frequency of salient beliefs related to the health and quality attributes of organic food among Czech consumers is also found in the OECD study [2011] and seems to be rather typical for organic food consumption worldwide [Boccaletti 2008]. Interestingly, however, Czech consumers seem to rate the importance of health-related motives relative to the importance of environmental motives much higher than consumers in European countries with a developed organic market such as France, Italy, Norway, Netherlands or Sweden, and more similarly to consumers in Canada, Australia or Mexico [OECD 2011]. The higher importance attached by Czech consumers to health-related beliefs relative to environmental ones is also apparent in other empirical studies [cf. Ogilvy 2008; Urban, Ščasný and Zvěřinová 2008; Zvěřinová 2011; Živělová and Jánský 2006, 2007a].

Besides these purely descriptive results, three studies also attempt to test a hypothesis about the factors behind the intention to consume organic food (or 'willingness to pay' for it, WTP) and past consumption of organic food. Two of the studies focus on determinants of willingness to pay for organic food [Urban and Ščasný 2007; Urban, Ščasný and Zvěřinová 2008], exploiting data from a survey of a representative sample of the adult population of the capital city of Prague $(N=351)$. Neither of the two studies tests the complete model of the theory of planned behaviour and instead they use two of its elements, attitudes and subjective norms, in combination with socio-economic and psychological variables, to explain the willingness to pay for organic food (which is conceptualised as the 
intention to spend money on organic food). The results of the two studies suggest that past purchase behaviour can be explained by subjective norms, pro-environmental attitudes and the presence of children in the household; the probability of non-zero WTP is positively affected by subjective norms, the presence of children in the household, and a higher level of education, and is also higher for female respondents, and, finally, the absolute magnitude of WTP for organic food is positively affected by the age of the respondents, their educational attainment, their total expenditures on food and their income [Urban and Ščasný 2007]. In addition, there is also evidence of the considerable heterogeneity of factors that affect stated WTP for different food items (milk and yogurts, cheese, meat, eggs and fruit and vegetables) [Urban, Ščasný and Zvěřnova 2008].

Finally, the work by Zvěřinova [2011] which exploits two samples of the adult population representative of the capital city of Prague $(n 1=330)$ and the region of Znojmo $(n 2=354)$ is probably the most complete attempt to use the theory of planned behaviour in the context of organic food consumption in the Czech Republic. This study finds that the probability of organic food purchase (indicated by past purchase behaviour) is positively affected by present intention to consume organic food, knowledge of organic food, knowledge of the correct organic logo, and residence in the capital of Prague (as opposed to the rural Znojmo region). Furthermore, the study also reveals that the intention to consume organic food is affected by (directly measured) attitudes and subjective norms, but not by perceived behavioural control. When the author replaces the direct measures of TPB constructs with indirect ones in order to explore the belief-basis of norms, attitudes and perceived behavioural control, she finds that attitudes related to the health, quality and taste attributes of organic food and (injunctive) subjective norms related to partner, parents and own children have the strongest effect on the intention to consume organic food, while perceived behavioural control has, again, no direct effect on intention.

\section{The theory of planned behaviour}

The theory of planned behaviour (TPB), proposed by I. Ajzen [1985, 1991] as a modification of the earlier theory of reasoned action [Fishbein and Ajzen 1975], postulates that 'planned' behaviour (i.e. the behaviour that is at least partly reflected upon by the actor) can be best predicted from the intention to act and perceived behavioural control. The intention to act is, in turn, determined by attitudes, subjective norms, and perceived behavioural control related to particular behaviour. Specifically, TPB predicts that the intention to act will be stronger when attitudes and subjective norms towards a behaviour are favourable and when there is greater perceived behavioural control (PBC) [Fishbein and Ajzen 2009: 21]. ${ }^{1}$

${ }^{1}$ However, the role of perceived behavioural control as a factor of intention is probably less well known than the role of the two remaining factors. As a matter of fact, a higher 
Figure 1. Graphic representation of the theory of planned behaviour

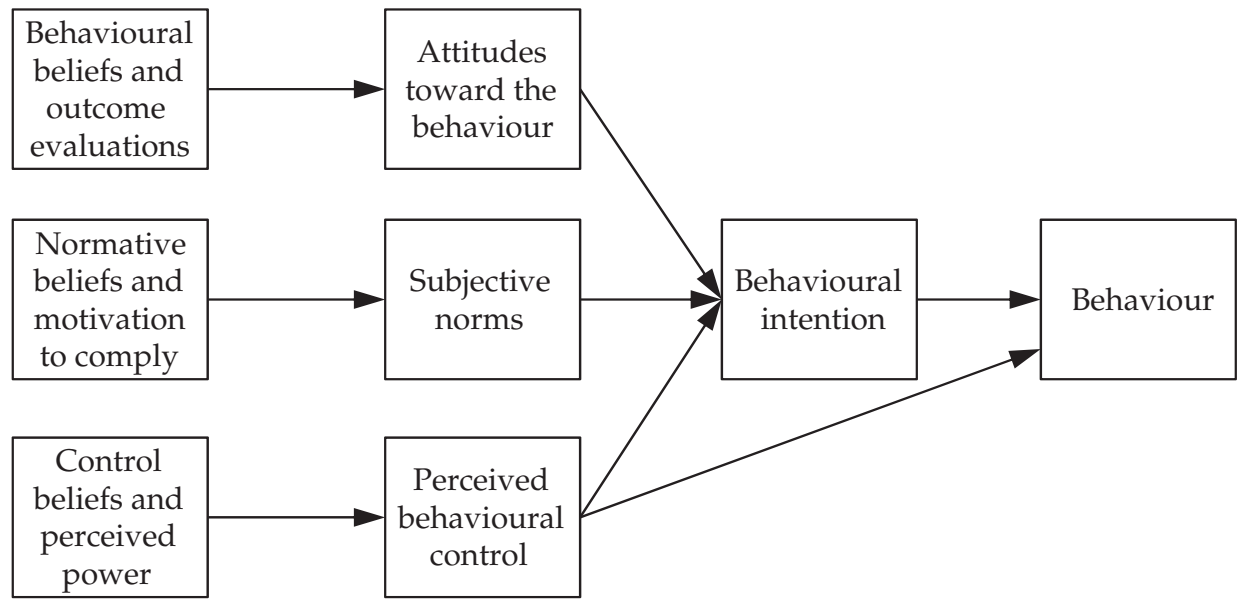

Source: Ajzen [2005: 21].

Finally, TPB assumes that attitudes, subjective norms and perceived behavioural control are formed based on attitudinal, normative and control beliefs and their respective evaluations. Attitudes are conceptualised in TPB as 'a latent disposition or tendency to respond with some degree of favorableness or unfavorableness to a psychological object' where 'the attitude object can be any discriminable aspect of an individual's world, including behavior' [Fishbein and Ajzen 2009: 76], subjective norm as the 'individual's perception that most people who are important to her think she should (or should not) perform a particular behavior' [Fishbein and Ajzen 2009: 131], and perceived behavioural control as 'people's perception of the degree to which they are capable of, or have control over, performing a given behavior' [Fishbein and Ajzen 2009: 64]. A convenient graphic representation of TPB is presented in Figure 1.

The theory of planed behaviour has been applied in over 1000 empirical applications in such diverse areas as transportation behaviour, consumption behaviour, social deviance and school performance, but the largest part has been realised in the area of health behaviour (see the complete bibliography in Ajzen [2012]). Several studies have also applied the theory of planned behaviour to an

PBC does not automatically lead to a greater intention to perform the behaviour, because 'the fact that I am capable of performing a behavior does not necessarily imply that I will intend to do so' [Fishbein and Ajzen 2009: 181]. PBC is also thought to mediate the effect of subjective norms and attitudes on intention, although empirical evidence which would support this contention is relatively scarce [Fishbein and Ajzen 2009: 181]. In any case, the correlation found between PBC and intention across various meta-analytical studies was positive and substantial, ranging between 0.35 and 0.46 [Fishbein and Ajzen 2009: 181]. 
explanation of organic food consumption [Arvola et al. 2008; Cook, Kerr and Moore 2002; Dean, Raats and Shepherd 2008; Gracia and de Magistris 2007; Saba and Messina 2003; Sparks and Shepherd 1992; Tarkiainen and Sundqvist 2005; Thøgersen 2009]. Only four of these studies focused on the prediction of purchase behaviour [Gracia and de Magistris 2007; Saba and Messina 2003; Tarkiainen and Sundqvist 2005; Thøgersen 2009], while the remaining studies explain the intention to purchase organic food. As far as we are aware, applications of TPB in the Czech Republic are very limited in number: three studies [Urban and Ščasný 2007; Urban, Ščasný and Zvěřinová. 2008; Zvěřinová 2011] apply TPB or its elements to an explanation of organic food consumption in the Czech Republic (see the previous section for a discussion of their results) and another study [Urban, Zvěřinová and Proková 2010] uses TPB to explain energy-conserving behaviour among university students. ${ }^{2}$

The explanatory power of TPB models of organic food consumption varies noticeably. The explained variance of the intention to purchase organic food ranges between $24 \%$ in the case of the intention to purchase organic vegetables over the next week [Cook, Kerr and Moore 2002] and 83\% for the intention to purchase organic tomatoes and processed organic sauce [Thøgersen 2009]. Also the explained variance of organic food consumption varies considerably, between $18 \%$ for the purchase of organic tomatoes and tomato sauce [Thøgersen 2009] and $82 \%$ for the purchase of organic bread and flour [Tarkiainen and Sundqvist 2005]. Judged by the explanatory power of the models which are used in the social sciences, the explanatory power of TPB seems to be relatively high also in the domain of organic food consumption.

\footnotetext{
${ }^{2}$ After we submitted the final version of this paper, Lukas Zagata's application of TPB on organic food consumption in the Czech Republic was published [Zagata 2012]. We would like to acknowledge this application at least in passing because in many ways it overlaps with our present work and its main results are similar to ours (surprisingly similar are the effects of attitudes and social norms on intention found in both studies, and the finding that $\mathrm{PBC}$ has the weakest effect of the three predictors of intention). Zagata's application of TPB to organic food consumption is superior to ours specifically in that: (a) it uses a larger sample of consumers $(N=1054)$ than we do, $(b)$ it investigates the role of behavioural, normative, and control beliefs, (c) it employs a better measurement model for intention and perceived behavioural control, and (d) it aims to analyse the relationship between intention and actual purchase behaviour. Our study, is different from Zagata's work, in that, besides the fact that we focus on the role of descriptive norms, we are using a sample representative of the Czech adult population (whereas his study draws on a sample representative of people who are actually buying organic food), and therefore only the results of our study can, strictly speaking, be generalised to the general population of the Czech Republic. We also have some reservations with respect to how actual purchase behaviour is measured in Zagata's study (as a frequency of past purchase behaviour). Although this approach in not unknown in the literature [see, e.g., Thøgersen 2009] it is not quite consistent with the TPB that expects the present intention to be a predictor of future behaviour and not of past behaviour [cf. Fishbein and Ajzen 2009].
} 


\section{Normative influences in the TPB context}

Although the merits of TPB are widely recognised, ever since its formulation in the mid-1980s, there have been attempts to include new variables in its framework and increase thus its predictive power. Most frequent extension of the TPB consisted of inclusion of belief salience, past beliefs and habits, moral norms, selfidentity and differentiation between perceived behavioural control and self-efficacy (see the review by Conner and Armitage [1998]). The empirical application of TPB in the domain of pro-environmental behaviour has especially benefited from the inclusion of personal norms, past behaviour and self-identity [Staats 2003]. As a matter of fact, I. Ajzen has invited efforts to extend TPB in its original formulation by claiming that TPB is principally open to addition of new variables, under the condition that it is well demonstrated that such variables consistently and significantly improve the predictive capacity of TPB [Ajzen 1991: 199].

One of the extensions of the original formulation of TPB that has received relatively less attention, but which has been recognised recently as an issue with important theoretical and practical implications is the inclusion of descriptive norms in the TPB framework. This extension of TPB is also of some relevance with respect to the subject matter of this study because normative factors can be expected to be important in a situation where environmental, social and altruistic motives play a role, such as in the cases of pro-environmental behaviour [see, e.g., Staats 2003] or, in our case, organic food consumption.

The concept of subjective norms as originally included in TPB refers to 'perceived social pressure to perform or not to perform the behavior' [Ajzen 1991: 188]. This rather restrictive conceptualisation of normative factors in TPB (see also the discussion in Fishbein and Ajzen [2009: 131]) was mentioned as one of the reasons for the fact that from the three predictors of intention, social norms are found to have the weakest effect (see the meta-analysis by Armitage and Conner [2001]) or even no effect on intention in empirical applications [Conner, Norman and Bell 2002; Mahon, Cowan and McCarthy 2006; Terry and O'Leary 1995]. Inadequate conceptualisation of normative aspects in TPB was one of the reasons why several studies sought to extend the TPB framework with descriptive norms, where descriptive norms are usually defined as perceptions of what other people do [Deutsch and Gerard 1955].

There are several reasons for the inclusion of descriptive norms in the TPB framework besides improved conceptualisation of the normative component and improved predictive power of the model (improved predictive power is discussed further below). First, injunctive and descriptive norms may actually be in conflict (as for example when adults who smoke and drink alcohol advise their children not to do so) and are frequently found to interact in a relatively complex way which may amplify or attenuate the total effect of normative component [see, e.g., Smith and Louis 2010]. Perhaps even more importantly, the mechanism that underlies the effect of descriptive norms on intention and behaviour need not be 
identical with that of injunctive norms. It is recognised that the direct effect of descriptive norms on behaviour and behavioural intention is frequently not backed by either the direct coercive or punishment/reward power of the referent group [Fishbein and Ajzen 2009: 131]. This is for instance the case when the referents' behaviour is used to infer information about the adaptive behaviour of others, including information about most efficient choices, necessary means, possible barriers, etc. Observation of the behaviour of others may also be used to infer the attitudes of others, their personal norms, and their expectations concerning the behaviour of other people, i.e. injunctive norms [Cialdini, Kallgren and Reno 1991; Fishbein and Ajzen 2009: 132; Rivis and Sheeran 2003a: 220; Thøgersen 2006: 250]. In this way, descriptive norms can also have an indirect effect on intention and behaviour mediated by attitudes and perceived behavioural control [Fishbein and Ajzen 2009: 132]. However, it is not difficult to imagine instances when the descriptive norm can be actually backed by coercive power or by a punishment/reward mechanism, for instance in the form of recognition as a group member and/or by social stigmatisation. It is also important to note the fact that descriptive norms are different from injunctive norms in that they are usually less internalised than injunctive norms [Thøgersen 2006: 250].

A recent meta-analysis of 14 TPB studies, which included descriptive norms as an additional predictor of intention, gives support to these claims. It shows that descriptive norms have a significant effect on intention after controlling for other TPB variables and that the inclusion of descriptive norms increases the explained variance of intention by $5 \%$, and also that there is a moderate correlation between descriptive norms on the one hand and injunctive norms, attitudes and perceived behavioural control on the other [Rivis and Sheeran 2003]. An additive and independent effect of descriptive norms on intention is also found in a meta-analysis of TPB studies by Melnyk, van Harpen and van Trijp [2010]. Unfortunately, given the almost complete lack of studies other than correlational studies, the causal direction of the correlational patterns which exists between injunctive norms, descriptive norms, attitudes and perceived behavioural control is unclear.

Most of the studies that introduce descriptive norms as an additional variable in the TPB framework focus on health-related behaviour (see Rivis and Sheeran [2003] for their overview), three focus on healthy eating [Berg, Jonsson and Conner 2000; Nordrehaug Astrøm and Rise 2001; Povey et al. 2000], one on eating as such [Tuu et al. 2008], while no study has tested extended TPB within the context of organic food consumption. In any case, it is interesting to notice that of the four studies which test the addition of descriptive norms in the foodrelated context, only the study by Povey et al. [2000] finds no statistically significant effect of descriptive norms on intention when controlling for other TPB variables. 


\section{Table 1. Descriptive statistics of the population and samples}

\begin{tabular}{|c|c|c|c|c|}
\hline & $\begin{array}{l}\text { Czech popu- } \\
\text { lation }\end{array}$ & Sample & $\begin{array}{l}\text { Test statistic } \\
\text { (df) }\end{array}$ & $p$-value \\
\hline Number of observations & - & 252 & & \\
\hline Gender & & & $\chi^{2}<0.001(1)$ & 0.979 \\
\hline Males & $48.7 \%^{1}$ & $47.4 \%$ & & \\
\hline Females & $51.3 \%$ & $52.6 \%$ & & \\
\hline Age groups & & & $\chi^{2}=0.002(2)$ & 0.999 \\
\hline $18-39$ & $40.1 \%{ }^{2}$ & $38.7 \%$ & & \\
\hline $40-59$ & $32.5 \%$ & $34.8 \%$ & & \\
\hline $60+$ & $27.4 \%$ & $26.5 \%$ & & \\
\hline Highest educational attainment & & & $\chi^{2}=0.045(3)$ & 0.997 \\
\hline Primary and incomplete education & $19.1 \% \%^{1,3}$ & $26.1 \%$ & & \\
\hline Lower secondary & $34.9 \%$ & $35.6 \%$ & & \\
\hline Upper secondary and post-secondary & $32.9 \%$ & $24.9 \%$ & & \\
\hline Tertiary & $13.2 \%$ & $13.4 \%$ & & \\
\hline Marital status & & & $\chi^{2}=0.139(3)$ & 0.987 \\
\hline Never married & $40.2 \%^{1}$ & $22.9 \%$ & & \\
\hline Married & $42.1 \%$ & $57.3 \%$ & & \\
\hline Divorced & $10.4 \%$ & $9.9 \%$ & & \\
\hline Widowed & $7.3 \%$ & $9.9 \%$ & & \\
\hline Municipality size groups & & & $\chi^{2}=0.008(4)$ & $>0.999$ \\
\hline less than 5000 inhabitants & $38.0 \%^{1}$ & $36.4 \%$ & & \\
\hline 5000 to 19999 inhabitants & $18.4 \%$ & $17.8 \%$ & & \\
\hline 20000 to 49999 inhabitants & $11.6 \%$ & $12.6 \%$ & & \\
\hline 50000 to 99999 inhabitants & $9.9 \%$ & $8.3 \%$ & & \\
\hline 100000 or more inhabitants & $22.1 \%$ & $24.9 \%$ & & \\
\hline $\begin{array}{l}\text { Average net monthly per capita income } \\
\text { of the household [CzK] }\end{array}$ & $12206^{4}$ & 12476 & $\mathrm{t}=0.702(251)$ & 0.483 \\
\hline Std. dev. & - & 6105 & & \\
\hline Average household size & $2.5^{4}$ & 2.7 & $\mathrm{t}=2.646(251)$ & 0.009 \\
\hline Std. dev. & - & 1.2 & & \\
\hline
\end{tabular}

Notes: ${ }^{1}$ population data from CZSO [2011a]; ${ }^{2}$ population data from CZSO [2011b]; ${ }^{3}$ Czech population aged $15+;{ }^{4}$ data on Czech households are from CZSO [2011c].

Source: Authors' calculations based on CZSO data [2011a, 2011b, 2011c]. 


\section{Data}

The data exploited in this study come from a survey of the general adult population of the Czech Republic. The survey was devised by Charles University Environment Center and the data were collected in November and December 2010 by a professional opinion poll agency, in compliance with ISOMAR standards. The survey took the form of structured face-to-face computer-assisted interviews and used quota sampling with quotas for age, gender, education level and size of place of residence.

The socio-economic and demographic characteristics of our sample are displayed in Table 1. The total sample consists of 252 observations. The sample resembles the general adult population of the Czech Republic quite well in terms of gender, age, educational attainment, marital status and municipality size as there are no significant statistical differences between the sample and the population in terms of these characteristics (see Table 1). The average household size and the average net per capita household income are quite similar in our sample and in the population of Czech households. However, the comparison of these two variables is rather indicative because their population statistics come from a micro-census that sampled households rather than individuals. This is also the reason why the average household size reported by respondents is significantly higher than average household size in the Czech Republic (see Table 1 and the notes below Table 1). Overall, these results give us no reason to doubt the representativeness of our sample.

\section{Sample size}

Obviously, the relatively small size of our sample poses some limitations for the present study. Most importantly, a small sample size increases sampling error and decreases the power of statistical tests, thus increasing probability of a type II error.

There is no simple rule of thumb as to the sample size needed for structural equation modelling because this depends on the normality of data, the estimation method, the complexity of the model, and the patterns of relationships which exist between the observed variables. Some authors argue that as many as 20 observations are needed for each free parameter estimated [Tanaka 1987], while others argue that 10 [Schreiber et al. 2006] or perhaps 5 observations [Bentler and Chou 1987] per one free parameter are sufficient. In any case, it is contended that the critical sample size for sufficient statistical power of the structural models is 200 observations

The most complex model that we report in this study contains 45 free parameters, meaning that this study, which uses data consisting of 252 observations, meets Bentler and Chou's [1986] recommendation of a minimum of 5 ob- 
servations per each free parameter and also fulfils the requirement of a minimum of 200 observations [Garver and Mentzer 1999].

\section{Measures and method}

\section{Measures}

Measures of latent constructs, i.e. subjective norms, attitudes, perceived behavioural control and intention, are adopted primarily from Ajzen [2002] and Francis et al. [2004]. Bearing in mind the principle of correspondence of TPB constructs [Ajzen 1991, 2005], we have defined the target behaviour as 'respondent's buying of organic food in the next month' and formulated indicators of all TPB constructs accordingly. The wording of measurement items is displayed in Table 2.

\section{Subjective norms}

We follow Ajzen's [2002] recommendation and a common practice in the TPB research and include two indicators of descriptive $(s n 1, s n 2)$ and two indicators of injunctive norms $(s n 3, s n 4)$ - see Table 2 for the wording of the items. As noted earlier, descriptive subjective norms are a person's perception of whether significant others do perform the target behaviour, while injunctive norms are a respondent's perception that significant others approve of his or her enacting of the target behaviour.

\section{Attitudes}

The attitudinal measure used in the survey consists of five items, three of which are more specific (at2, at3, at4) and two more general (at1, at5) - see Table 3 for their wording. All items are worded as instrumental scales.

\section{Perceived behavioural control}

Perceived behavioural control is measured with two items, one item which captures controllability or the perceived level of control that the person has over the purchase of organic food ( $p b c 1)$, and the other that captures self-efficacy or perceived ability to purchase organic food ( $p b c 2)$ - see Table 2 for their wording. The two items should theoretically [see Ajzen 2002] load on the same latent construct.

\section{Intention to purchase organic food}

The intention to purchase organic food in the next month was measured by a single item, with the respondents indicating their level of agreement with the 
statement 'I intend to buy organic food in the next month' on a 7-point Likerttype scale. The use of the single item measure precludes us from estimating the measurement error of the intention scale.

All measurement items used in this study had been previously employed in other studies on organic food consumption to measure attitudes and subjective norms [Arvola et al. 2008; Dean, Raats and Shepherd 2008; Sparks and Shepherd 1992; Thøgersen 2009; Thøgersen and Ölander 2006], perceived behavioural control [Arvola et al. 2008; Dean, Raats and Shepherd 2008; Thøgersen 2009] and intention [Sparks and Shepherd 1992; Tarkiainen and Sundqvist 2005; Thøgersen 2009].

\section{Method}

The data are analysed using structural equation modelling [Bollen 1989]. SEM is very advantageous for the purpose of our study, specifically because it allows us to test the empirical model derived from the theory of planned behaviour using latent variables. SEM is also more general than regression analysis with observed variables and allows us to specify measurement models for latent variables and estimate their measurement errors.

One of the important steps in the adoption of SEM is the choice of appropriate estimation method. We opted for maximum likelihood (ML) in this study. Strictly speaking, other estimators such as asymptotically distribution

Figure 2. 'I intend to buy organic food in the next month' (relative frequencies, sample, $N=252$ )

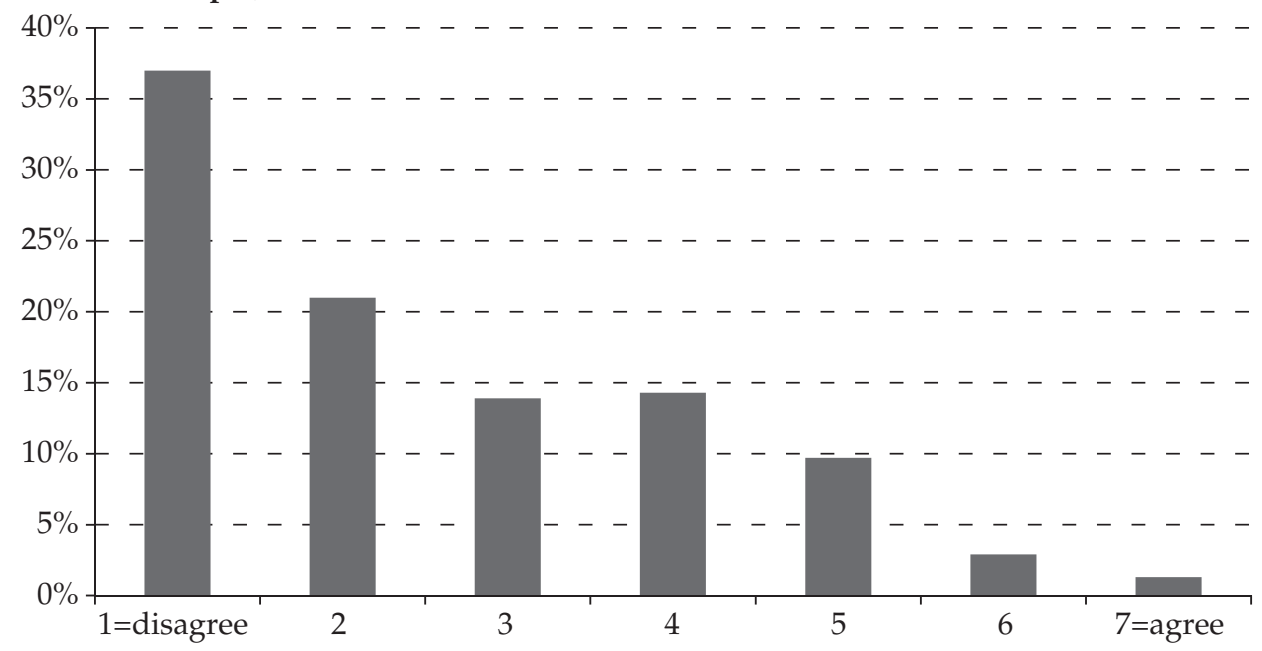

Source: Authors' calculations. 


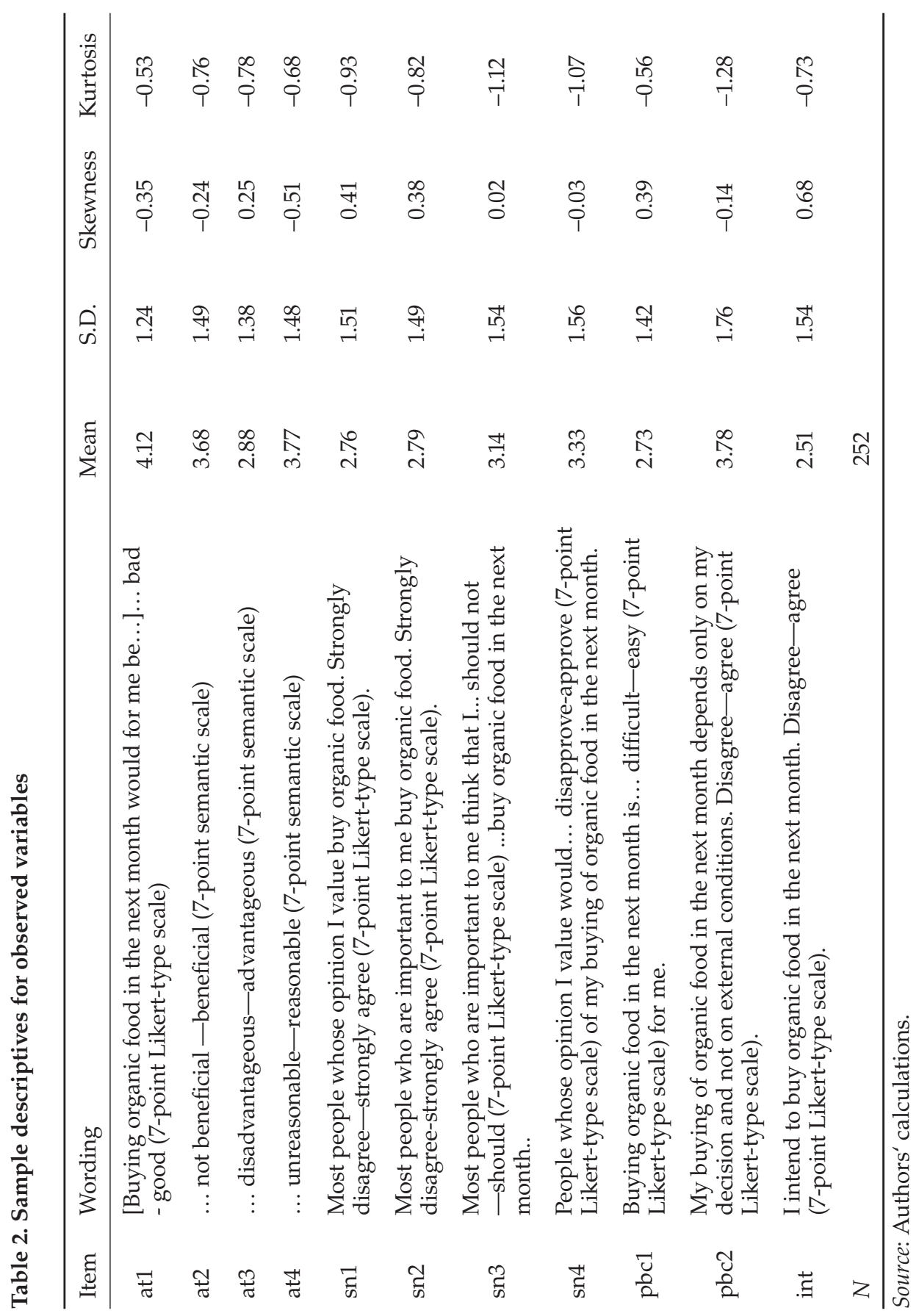


free method [Browne 1984] or weighted least squares mean variance adjusted estimator [Muthén and Muthén 2010] would be more appropriate with the ordinal data available for this study. However, these alternative estimation methods require very large sample sizes, so in our case their use is effectively ruled out. Nonetheless, it has been shown that the maximum likelihood estimator performs relatively well with categorical data that have more than five categories with a distribution that resembles normal distribution [Rigdon 1998] and also that this estimation method is relatively robust to mild departures from multivariate normality [McDonald and Ho 2002; West, Finch and Curran 1995]. The models are estimated in 'Mplus', version 6.1 [Muthén and Muthén 2010].

We report and assess several types of fit indices as suggested in the literature [Hoe 2008; McDonald and Ho 2002]. Specifically we report one absolute fit index (chi-square, resp. relative chi-square), one relative fit index (Tucker-Lewis index-TLI), and two non-centrality based indices (Comparative Fit Index-CFI and Root Mean Square Error of Approximation-RMSEA). We accept the following cut-off values for good fitting models that were recommended in the literature: relative chi-square $<3$ [Kline 2004], TLI $>0.9$, CFI $>0.9$, and RMSEA $<0.08$ [cf. Hoe 2008; Hu and Bentler 1998; Kline 2004]. In addition to global fit indices, we also assess normalised correlation residuals as recommended by McDonald and Ho [2002] but we do not report complete matrices of residuals to save space (these can be requested from the authors).

We estimated two structural models: Model 1 is a standard TPB model and Model 2 is the extended TPB model where descriptive norms are introduced as an additional predictor of intention.

\section{Results}

The sample relative frequency of respondents' agreement or disagreement with the statement designed to measure the intention to buy organic food over the period of the next month is displayed in Figure 2. The distribution of answers is right-skewed with only a few observations in the 'completely agree' category. The data descriptives are reported in Table 2. Because we could observe a very low frequency (three observations or less) of the polar answer category 7 not just for intention but also in the case of attitudinal indicators, indicators of social norms and also indicators of perceived behavioural control, we merged this category with answer category 6 so that all of these indicators took discrete values from 1 to 6 .

\section{Normality of the data}

Before we proceed to testing the models, we shall examine whether the requirement of multivariate normality of the data, an important assumption of the ML 


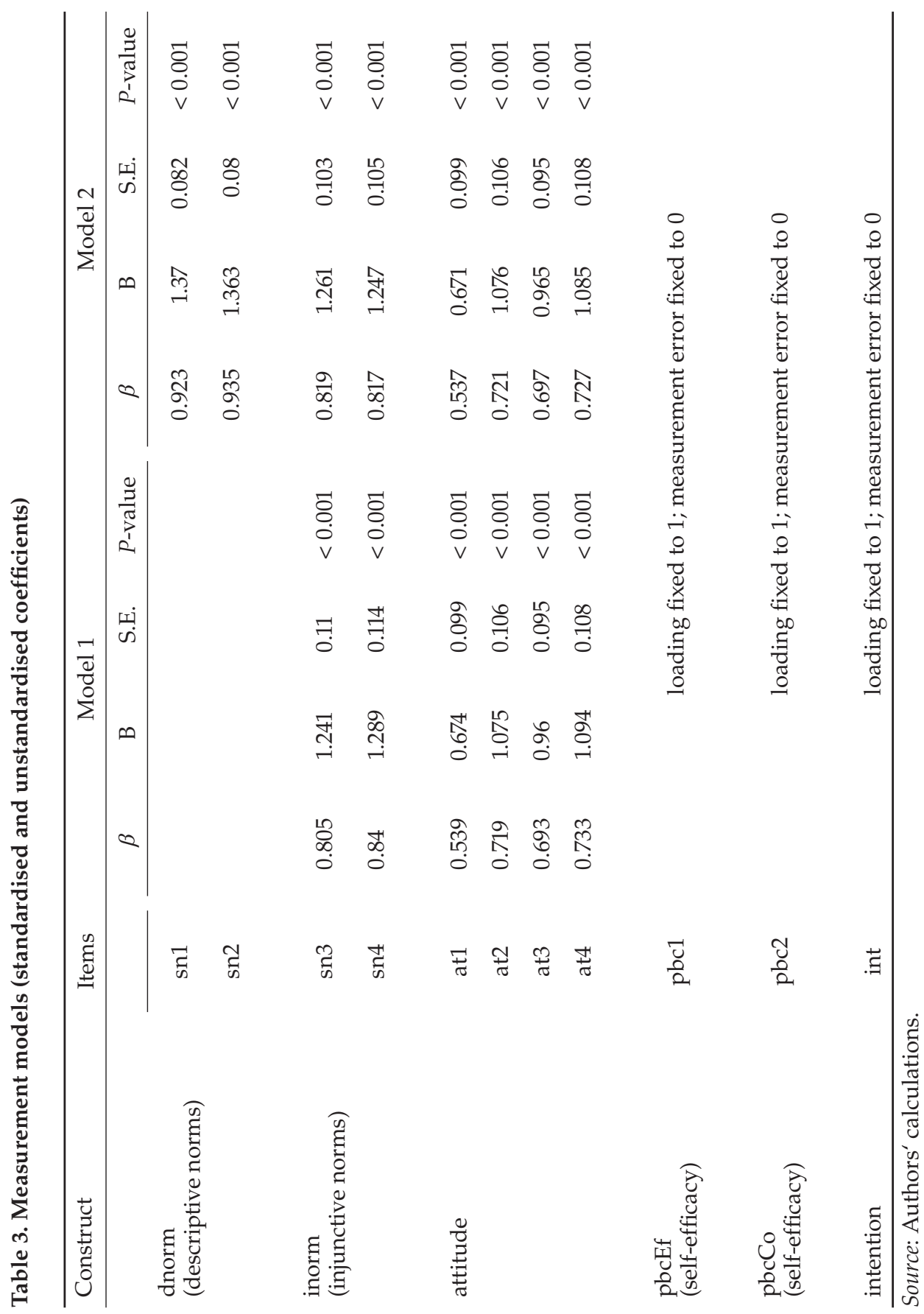




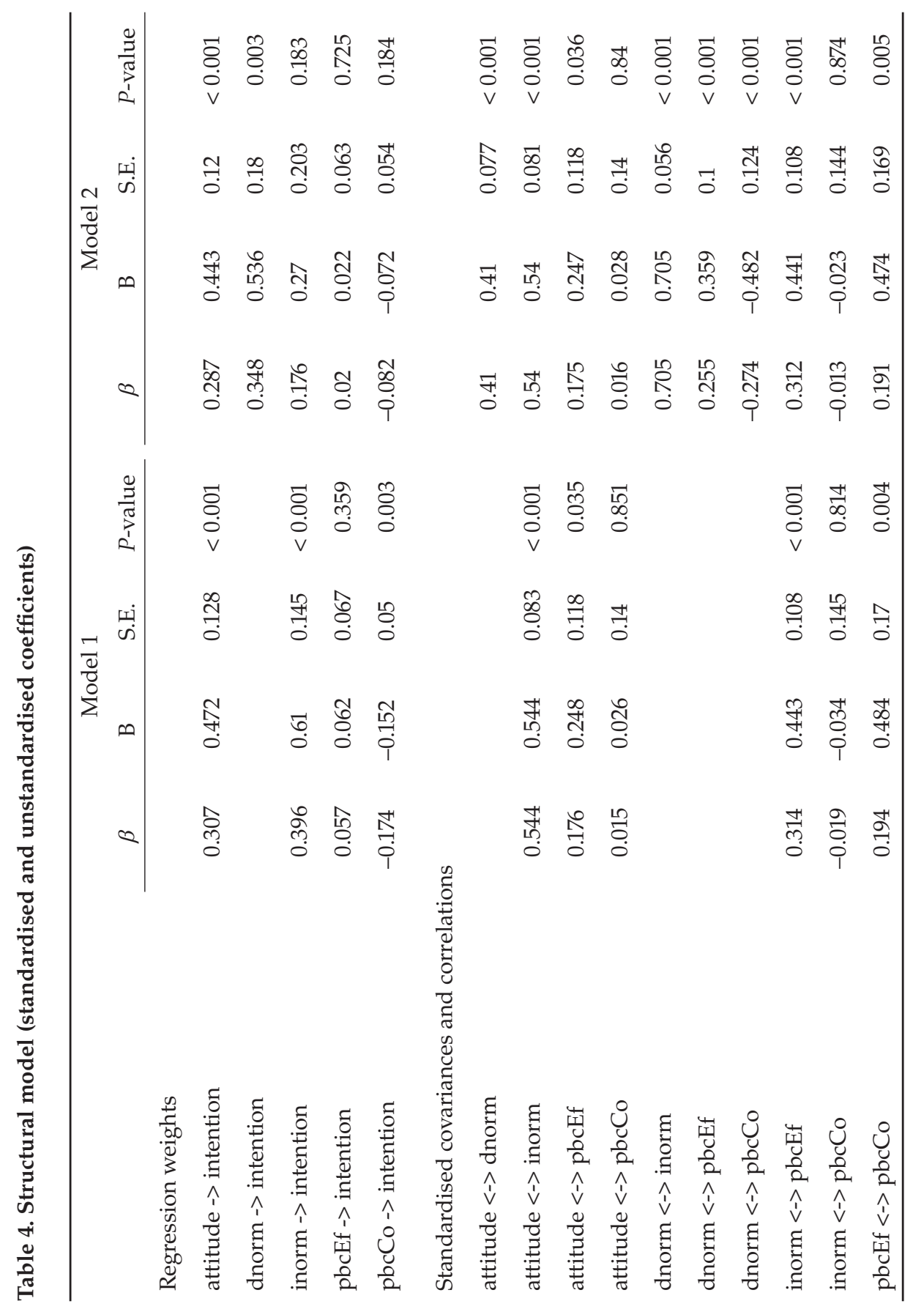




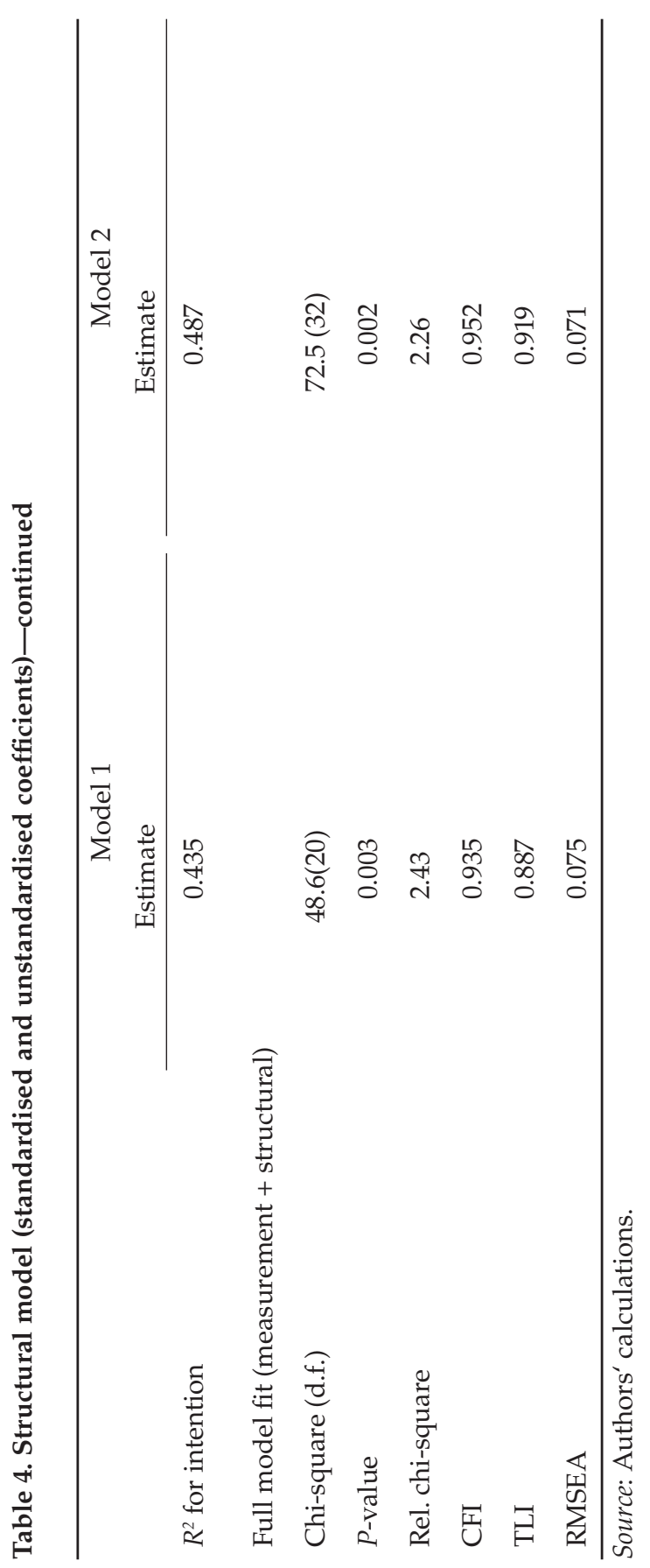


estimator, is met. The absolute values of the indices of the univariate skewness of the data (see Table 2) are mostly below the threshold of 0.5 and always below the cut-off value of 1 suggested by Bulmer [1979] as an indication of approximate symmetry and slight skewness, respectively. Also, the absolute values of indices of univariate kurtosis are nowhere near the value of 8 , suggested as a cut-off value for extreme kurtosis that would affect the ML estimates [Kline 2004: 63]. Finally, we test multivariate normality with generalised Shapiro-Wilk's test for multivariate normality proposed by Villasenor Alva and Estrada [2009] and implemented in the package mvShapiroTest in the statistical environment $R$. The test fails to reject the null hypothesis that the data are distributed multivariate normal at the 0.01 level of statistical significance. Since our investigation has revealed that our data depart from the requirement of multivariate normality only slightly, and since all variables in the dataset have more than five outcome categories, we believe that the ML estimator can produce reliable estimates.

\section{Measurement models}

Before fitting the full model, we assess the fit and other properties of the measurement models for each latent construct as advised in the literature [Anderson and Gerbing 1988; Hoe 2008; McDonald and Ho 2002]. Specifically we assess the internal consistency reliability of the measures using Cronbach's alpha, the unidimensionality of the measures using principal component analysis, convergent validity by inspecting the size, and the statistical significance of the factor loadings and discriminant validity by inspecting the size and confidence intervals of correlations between latent constructs.

The measurement model for subjective norms, which assumes that injunctive and descriptive items load on different latent variables, fits the data very well (chi-square $=2.1$ with 1 d.f., $p$-value $<0.14$, rel. chi-square $=2.1$, RMSEA $=0.071$, $\mathrm{CFI}=0.997$, TLI $=0.984)$ and the two scales seem to be reliable $(\mathrm{CR}=0.926$ for descriptive norms and 0.802 for injunctive norms). In addition, the convergent validity (see Table 3) and the discriminant validity of this measurement model (see Table 4) seem to be sufficient.

The attitude scale composed of the five attitudinal items (at1 through at4) has good internal consistency reliability $(\alpha=0.779)$ and forms a one-dimensional scale (the eigenvalue of the first factor extracted by principal component analysis is 2.838). Nevertheless, confirmatory factor analysis reveals that the one-factor measurement model composed of five items does not fit the data very well (chisquare $=54.57$ with 5 d.f., $p$-value $<0.001$, rel. chi-square $=10.9$, RMSEA $=0.215$, $\mathrm{CFI}=0.843, \mathrm{TLI}=0.686$ ). Anderson and Gerbing [1988] argue that in similar cases the deletion of an indicator from the measurement model is a more desirable remedy to a misfit of the measurement model than the ad hoc introduction of correlated measurement errors or the use of an indicator related to multiple factors, 
because these two latter solutions would make the interpretation of underlying latent constructs difficult. In addition, an independent cluster basis requirement for measurement model identification severely limits our ability to test more complex measurement models with our data. For these reasons we omit the item with the lowest loading on the underlying latent factor (at5) from the measurement model. The ensuing measurement model fits the data relatively well (chisquare $=9.049$ with 2 d.f., $p$-value $<0.011$, rel. chi-square $=4.5$, RMSEA $=0.128$, $\mathrm{CFI}=0.962, \mathrm{TLI}=0.890)$ and has sufficient composite reliability $(\mathrm{CR}=0.767)$. We shall retain this model for further analysis.

The two indicators of perceived behavioural control $(p b c 1, p b c 2)$ produce a scale with very low internal consistency reliability $(\alpha=0.31)$. In addition, principal component analysis reveals that the one-dimensionality of this measure is dubious (the eigenvalues are 1.19 and 0.90 for the first and second factors extracted). For these reasons we decided to enter the two indicators in the structural model independently. This is equivalent to specifying a measurement model in which the observed variables $p b c 1$ and $p b c 2$ load respectively on the two latent variables $p b c E f$ and $p b c C o$ with the two loadings fixed to 1 and the measurement errors fixed to 0 as displayed in Table 3.

After the adjustments, the convergent validity of the measurement models seems to be good, with all factor loadings substantially and significantly different from 0 (see Table 3). The estimated correlations between latent variables are relatively high (see Table 4), but statistically different from 1, suggesting sufficient discriminant validity.

\section{Test of the TPB model}

The fit of the empirical model derived from the TPB (Model 1) and the estimates of structural parameters are reported in Table 4, while the parameters from its measurement model are displayed in Table 3. The fit of Model 1 seems to be sufficient (the relative chi-square and the RMSEA are below and the CFI above the thresholds), but not superb (the chi-square test is significant with a $p$-value of 0.003 and the TLI is just below the 0.9 threshold). An inspection of normalised residual correlations (not displayed here) reveals that the misfit of the model is evenly distributed over the whole matrix, which also supports the contention that the model is an acceptable approximation of the data. Model 1 explains as much as $44 \%$ of the variability in intention.

The estimates of the structural path coefficients for Model 1 (see Table 4) reveal that injunctive norms and attitudes have, as expected, a significant and positive effect on intention. The controllability facet of perceived behavioural control $(\mathrm{pbc \textrm {Co }})$ has a significant but negative effect on intention (the TPB postulates its positive effect), while efficacy has no significant effect on intention. The reverse sign of the $p b c C o$ is not in line with the general expectations of the theory 
of planned behaviour (see the sub-chapter above on the TPB) and also inconsistent with the empirical findings of meta-analytical studies (see note 2 ). We discuss and interpret these results more thoroughly in the concluding section.

\section{Test of the extended model}

The fit of the extended TPB model (see Model 2 in Table 4) seems to be sufficient as measured by all fit indices, except for the chi-square value, which is significant (a $p$-value of 0.0003). Model 2 explains 49\% of the variability of intention, meaning that the addition of descriptive norms in the models increases the explained variance of intention by 5 percentage points.

The estimates of path coefficients for Model 2 (see Table 4) reveal that only attitudes and descriptive norms (dnorm) now have a direct effect on intention, while the effect of injunctive norms (inorm) and the effects of the two facets of perceived behavioural control $(p b c E f, p b c C o)$ have shrunk and are all now insignificant, although their directions remain the same as in Model 1. The suppression of the path coefficients after the introduction of descriptive norms into the model is most likely caused by collinearity due to descriptive norms being highly correlated with injunctive norms $(\mathrm{r}=0.71)$, and moderately correlated with the efficacy facet of perceived behavioural control or $\operatorname{pbcEf}(\mathrm{r}=-0.42)$ and also with the controllability facet of perceived behavioural control or pbcCo $(\mathrm{r}=0.36)$. In any case, these results seem to suggest that descriptive norms have an effect on behavioural intention, although this effect does not appear to be completely independent of injunctive norms and perceived behavioural control.

\section{Discussion}

The organic system of food production is seen by many as a way of decreasing the environmental burden of food consumption. The choice of organic over conventional food is usually driven by many motives, including ones related to social and environmental responsibility, economic incentives and barriers, and by factors related to one's own well-being and altruistic concerns for the well-being of family members. Czech consumers have become interested in organic food relatively recently, which has resulted in the fast growth of the Czech organic market. However, despite this trend, surprisingly little is known about the factors that motivate Czech consumers to prefer organic food over conventional. The studies that have focused on organic food consumption in the Czech Republic to date have been either purely descriptive or used samples representative of specific sub-populations. This study is the first that uses the theory of planned behaviour to explain the intention of the Czech adult population to purchase and consume organic food.

The present study shows that the TPB is successful in explaining the intention of Czech consumers to buy organic food. We find that in particular consum- 
ers' attitudes and their subjective norms have a strong effect on behavioural intention, while there is little or even no effect of perceived behavioural control on intention. Our results with respect to attitudes and subjective norms are well in line with empirical evidence, as attitudes and subjective norms have been shown to affect the intention to consume organic food in the Czech Republic [Urban and Ščasný 2007; Urban, Ščasný and Zvěřinová 2008; Zvěřinová 2011] and elsewhere [Arvola et al. 2008; Cook, Kerr and Moore 2002; Dean, Raats and Shepherd 2008; Sparks and Shepherd 1992; Thøgersen 2009]. Indeed, the finding that the self-efficacy facet of PBC has little or even no effect on intention is not unusual within the context of the consumption of organic food [see, e.g., Dean, Raats and Shepherd 2008] and is in fact also consistent with the findings of previous Czech TPB studies that have focused on organic food consumption [Urban and Ščasný 2007; Urban, Ščasný and Zvěřinová 2008; Zvěřinová 2011]. Moreover, the relatively weak effect of perceived behavioural control on the intention to consume organic food is also reflected in the design of several TPB studies, which do not even include PBC as an explanatory variable of intention [Arvola et al. 2008; Saba and Messina 2003; Tarkiainen and Sundqvist 2005]. Overall, our results suggest that both people with high and low intention perceive the purchase of organic food as relatively very difficult (a mean score of 2.73 on a 7-point scale, where 1 is 'easy' and 7 is 'difficult'), but unfortunately we can only speculate on what causes people to similarly perceive the difficulty. For instance, we may speculate that all consumers, irrespective of whether they purchase organic food or not, perceive the strong limits of the Czech organic market.

Perhaps a more surprising finding of the present study is the negative effect of the controllability facet of PBC on intention, which appears in Models 1 and 2, but which is statistically significant only in Model 1. This finding contradicts general expectations of the TPB [Fishbein and Ajzen 2009: 76] and empirical evidence from previous studies [ibid. 181]. Unfortunately, we can only speculate about what causes the negative direction of this effect. One possible explanation is that people who buy organic food (and presumably have a stronger intention to buy organic food) are actually more aware of the obstacles to buying organic food. Another possible interpretation is that people who buy organic food because other people around them do so (effect of descriptive norms) feel that they are being 'pushed' into buying organic food and, as a consequence, perceive a lower level of controllability over the purchase of organic food. This latter interpretation is also consistent with our finding that the controllability facet of PBC is negatively correlated with descriptive norms and that its effect on intention disappears when the descriptive norms are entered into the model as an additional predictor of intention. Yet another possible interpretation of our results with respect to the two facets of perceived behavioural control is that they are due to the poor measurement of these constructs. Low correlation between the two constructs actually seems to support this contention.

This work is the first study known to us that uses the TPB model extended with descriptive norms as an additional predictor of behavioural intention in the 
context of organic food consumption. Our results show that descriptive norms are an empirically distinct factor and that their inclusion in the TPB model increases its predictive power. We have found that the inclusion of descriptive norms in the TPB model suppresses the effect of injunctive norms and perceived behavioural control on intention due to the correlation of descriptive norms with other TPB constructs. This correlation not only poses problems for estimating reliable parameters for the empirical model, but it also creates difficulties for the theoretical interpretation of results.

An extremely interesting but difficult question to answer is how descriptive norms relate to perceived behavioural control, injunctive norms and attitudes. In this study we found that descriptive norms are correlated with all the predictors of behavioural intention, i.e. attitudes, injunctive norms and perceived behavioural control. These results are in line with the findings of previous studies, which found very similar relationships.

However, the question of the direction of causality that exists between these variables is not settled by existing research and our study can add very little to the discussion owing to the correlational evidence on which it is built. Nevertheless, even this limited evidence allows us to make one very interesting observation that became apparent in the course of our study and that is that the inclusion of descriptive norms in the TPB framework attenuates the effect of injunctive norms on intention to the point that the latter becomes statistically insignificant. This observation in fact supports Thøgersen's line of reasoning [2006: 258] that the effect of injunctive norms (or subjective social norms as he terms them) on pro-environmental behaviour may in many cases be just spurious, owing to the correlation between these two types of norms. Nonetheless, other interpretations of this interesting result are also possible. For instance it may be that people adjust their perceptions of what other people do (descriptive norms) based on what these other people tell them they should do (injunctive norms). Another interpretation is that injunctive norms simply do not play as prominent a role as descriptive norms do in the case of organic food consumption. Inadequate measurement of the two types of norms, resulting from the relative simplicity of the measurement model, also may have led to an attenuation of the effect of injunctive norms on the intention. We therefore strongly advise treating our results with caution and waiting until further evidence, preferably from experimental studies, makes the results more robust and their interpretation clearer.

From a practical point of view, our results indicate that Czech consumers are most likely influenced in their decision to consume organic food not just by their attitudes to organic food and by social pressure from significant others (injunctive norms) but also by the perception of what other people do. These results give some credit to the use of intervention methods, which aim to specifically influence these normative factors. A good prospect in this respect may be the social norms approach, used with success in health-related behaviour and substance-abuse prevention and other areas of behavioural intervention since the late 1980s (for a useful review of the theory see, e.g., Berkowitz [2004]). Social 
norms intervention seeks to change behaviour by focusing on peer influences and specifically by correcting misperceptions that lead to injunctive and descriptive norms, which are a source of undesirable behaviour. The social norms approach has also been tested in the environmental area and has proved practical as a means of promoting pro-environmental behaviour and minimising behaviour with adverse environmental consequences [Goldstein, Cialdini and Griskevicius 2008; Nolan et al. 2008]. Recently, Rettie, Barnham and Burchell [2011, 2012] proposed a normalisation approach for the marketing of green products that draws on the social norms approach and that involves the re-positioning of products in terms of their perceived greenness and their perceived normality (i.e. descriptive norms). The basic idea behind this intervention approach is the 'normalisation' of target behaviour, i.e. a strengthening of the belief that the behaviour is performed by many people and that it is, in fact, a 'normal' behaviour. Although the effectiveness of the normalisation approach as a marketing tool has not yet been tested empirically, together with the more established social-norms intervention these two approaches are very promising with respect to the marketing of organic products in the Czech Republic.

The limitations of the present study should be mentioned as well. We think that the relatively small sample size disadvantages our study specifically by decreasing its statistical power. The second limitation of the present study stems from the fact that we are using a very simple measurement model with only one indicator for three of the six constructs used in this study (intention and the two facets of perceived behavioural control), and as a result we cannot estimate the measurement error for these variables. Third, we should also acknowledge the limitation that derives from the design of the study, which focuses on explaining the intention to purchase organic food and not actual purchase behaviour. Although behavioural intention can be expected, under reasonable assumptions, to predict behaviour quite well, our results, strictly speaking, can be generalised only to predicting intention to purchase organic food and not to the actual purchase of organic food. Finally, we have to bear in mind that our data are crosssectional and therefore their relevance for testing causal hypotheses is lower than that of longitudinal or experimental data. On the other hand, we firmly agree agree with Rubin [1974] that no data can principally prove causal hypothesis and that different types of data (e.g. experimental, observational) differ only at the level of their relevance for testing causal hypotheses.

JAN URBAN is a sociologist and research fellow at the Charles University Environment Center. His main research interests are theories of pro-environmental behaviour, organic food and energy consumption, rebound effect, car ownership, and the application of nonmarket valuation methods.

MILAN ŠČASNÝ is a research fellow at the Charles University Environment Center. He acquired his PhD in economic theory at Charles University in Prague. His research ac- 
tivities cover several areas in the field of environmental economics, including valuation of health risks, analysis of residential energy demand, quantification of external costs, and distributional, economic and environmental impact assessment.

Iva ZvĚŘINOVÁ is junior research fellow at the Charles University Environment Center and a PhD candidate in sociology at the Faculty of Arts, Charles University in Prague. Her research has focused on environmentally significant behaviour, consumption of organic food, perception of risk, and energy use in households.

\section{References}

Aertsens, J., W. Verbeke, K. Mondelaers and G. V. Huylenbroeck. 2009. ‘Personal Determinants of Organic Food Consumption: A Review.' British Food Journal 111 (10): 1140-1167.

Ajzen, I. 1985. 'From Intentions to Actions: A Theory of Planned Behavior.' Action Control: From Cognition to Behavior: 11-39.

Ajzen, I. 1991. 'The Theory of Planned Behavior.' Organizational Behavior and Human Decision Processes 50 (2): 179-211.

Ajzen, I. 2002. Constructing a Theory of Planned Behavior Questionnaire. Unpublished manuscript. Retrieved 1 September 2011 (http://people.umass.edu/aizen/pdf/tpb. measurement.pdf).

Ajzen, I. 2005. Attitudes, Personality and Behavior. 2nd ed. Buckingham: Open University Press.

Ajzen, I. 2012. 'The Theory of Planned Behavior: A Bibliography.' Retrieved 3 July 2012 (http://people.umass.edu/aizen/tpbrefs.html).

Anderson, J. and D. Gerbing. 1988. 'Structural Equation Modeling in Practice: A Review and Recommended Two-Step Approach.' Psychological Bulletin 103 (3): 411-423.

Armitage, C. J. and M. Conner. 2001. 'Efficacy of the Theory of Planned Behaviour: A Meta-Analytic Review.' British Journal of Social Psychology 40: 471-499.

Arvola, A., M. Vassallo, M. Dean, P. Lampila, A. Saba, L. Lähteenmäki and R. Shepherd. 2008. 'Predicting Intentions to Purchase Organic Food: The Role of Affective and Moral Attitudes in the Theory of Planned Behaviour.' Appetite 50 (2-3): 443-454.

Baroni, L., L. Cenci, M. Tettamanti and M. Berati. 2007. 'Evaluating the Environmental Impact of Various Dietary Patterns Combined with Different Food Production Systems.' European Journal of Clinical Nutrition 61 (2): 279-286.

Bentler, P. M. and C.-P. Chou. 1987. 'Practical Issues in Structural Modeling.' Sociological Methods \& Research 16 (1): 78-117.

Berg, C., I. Jonsson and M. Conner. 2000. 'Understanding Choice of Milk and Bread for Breakfast among Swedish Children Aged 11-15 Years: An Application of the Theory of Planned Behaviour.' Appetite 34 (1): 5-19.

Berkowitz, A. D. 2004. The Social Norms Approach: Theory, Research, and Annotated Bibliography. Unpublished manuscript. Retrieved 3 July 2012

(http://www.alanberkowitz.com/articles/social_norms.pdf).

Boccaletti, S. 2008. 'Environmentally Responsible Food Choice.' Pp. 117-152 in Household Behaviour and the Environment: Reviewing the Evidence, edited by E. Ferrara and Y. Serret. Paris: OECD. 
Bollen, K. A. (ed.) 1989. Structural Equation Modeling: A Second Course. 1st ed. New York: Wiley-Interscience.

BÖLW. 2010. Zahlen, Daten, Fakten: Die Bio-Branche 2010. Berlin: Bund Ökologische Lebensmittelwitschaft e. V. (BÖLW). Retrieved July 3 July 2012 (http://www.boelw. de/uploads/media/pdf/Dokumentation/Zahlen_Daten_Fakten/ZDF2010gesamt. pdf).

Browne, M. W. 1984. 'Assymptotically Distribution Free Methods for the Analysis of Covariance Structures.' British Journal of Mathematical and Statistical Psychology 37: 62-83.

Bulmer, M. G. 1979. Principles of Statistics. Mineola, NY: Dover Publications.

Cialdini, R. B., C. A. Kallgren and R. R. Reno. 1991. 'A Focus Theory of Normative Conduct: A Theoretical Refinement and Reevaluation of the Role of Norms in Human Behavior.' Advances in Experimental Social Psychology 24: 201-234.

Conner, M. and C. J. Armitage. 1998. 'Extending the Theory of Planned Behavior: A Review and Avenues for Further Research.' Journal of Applied Social Psychology 28 (15): 1429-1464.

Conner, M., P. Norman and R. Bell. 2002. 'The Theory of Planned Behavior and Healthy Eating.' Health Psychology: Official Journal of the Division of Health Psychology, American Psychological Association 21 (2): 194-201.

Cook, A. J., G. N. Kerr and K. Moore. 2002. 'Attitudes and Intentions towards Purchasing GM Food.' Journal of Economic Psychology 23 (5): 557-572.

CZSO. 2011a. Preliminary Results of the 2011 Population and Housing Census. Prague: Český statistický úřad. Retrieved 3 July 2012 (http://www.czso.cz/sldb2011/eng/redakce. nsf/i/census_results).

CZSO. 2011b. Statistical Yearbook of the Czech Republic 2011. Prague: Český statistický úrad. Retrieved 3 July 2012 (http://www.czso.cz/csu/2011edicniplan.nsf/engpubl/ 0001-11-2010).

CZSO. 2011c. Household Income and Living Conditions 2010. Prague: Český statistický úřad. Retrieved 3 July 2012 (http://www.czso.cz/csu/2011edicniplan.nsf/engp/ 3012-11).

Dean, M., M. M. Raats and R. Shepherd. 2008. 'Moral Concerns and Consumer Choice of Fresh and Processed Organic Foods.' Journal of Applied Social Psychology 38 (8): 2088-2107.

Deutsch, M. and H. B. Gerard. 1955. 'A Study of Normative and Informational Social Influences upon Individual Judgment.' The Journal of Abnormal and Social Psychology 51 (3): 629-636.

Fishbein, M. and I. Ajzen. 1975. Belief, Attitude, Intention and Behavior: An Introduction to Theory and Research. Reading, MA: Addison-Wesley.

Fishbein, M. and I. Ajzen. 2009. Predicting and Changing Behavior: The Reasoned Action Approach. 1st ed. New York: Psychology Press.

Francis, J. F., P. Eccles, M. Johnston, A. Walker, J. Grimshaw, R. Foy, E. F. S. Kaner, L. Smith and D. Bonetti. 2004. Constructing Questionnaires Based on the Theory of Planned Behaviour: A Manual for Health Service Researchers. Newcastle upon Tyne: University of Newcastle. Retrieved 3 July 2012 (http://pages.bangor.ac.uk/ pes004/ exercise_psych/downloads/tpb_manual.pdf).

Garver, M. S. and J. T. Mentzer. 1999. 'Logistics Research Methods: Employing Structural Equation Modeling to Test for Construct Validity.' Journal of Business Logistics 20 (1): 33-57.

Goldstein, N. J., R. B. Cialdini and V. Griskevicius. 2008. 'A Room with a Viewpoint: Using Social Norms to Motivate Environmental Conservation in Hotels.' Journal of Consumer Research 35 (3): 472-482. 
Gracia, A. and T. de Magistris. 2007. ‘Organic Food Product Purchase Behaviour: A Pilot Study for Urban Consumers in the South of Italy.' Spanish Journal of Agricultural Research 5 (4): 439-451.

Hertwich, E., E. van der Voet, S. Suh, A. Tukker, A. Huijbregts, P. Kazmierczyk, P. Lenzen, J. McNeely and Y. Moriguchi. 2010. Assessing the Environmental Impacts of Consumption and Production: Priority Products and Materials. Nairobi: United Nations Environment Programme.

Hoe, S. L. 2008. 'Issues and Procedures in Adopting Structural Equation Modeling Technique.' Journal of Applied Quantitative Methods 3 (1): 76-83.

Hu, L.-T. and P. Bentler. 1998. 'Fit Indices in Covariance Structure Modeling: Sensitivity to Underparameterized Model Misspecification.' Psychological Methods 3 (4): 424-453.

Jungbluth, N., O. Tietje and R. Scholz. 2000. 'Food Purchases: Impacts from the Consumers' Point of View Investigated with a Modular LCA.' The International Journal of Life Cycle Assessment 5 (3): 134-142.

Kline, R. B. (ed.) 2004. Principles and Practice of Structural Equation Modeling. 2nd ed. London: The Guilford Press.

Kovanda, J. and T. Hák (eds). 2012. Progress Report of the Czech Republic's Strategic Framework for Sustainable Development. Prague: Ministerstvo životního prostředí.

Mahon, D., C. Cowan and M. McCarthy. 2006. 'The Role of Attitudes, Subjective Norm, Perceived Control and Habit in the Consumption of Ready Meals and Takeaways in Great Britain.' Food Quality and Preference 17 (6): 474-481.

McDonald, R. P. and M.-H. Ho. 2002. 'Principles and Practice in Reporting Structural Equation Analyses.' Psychological Methods 7 (1): 64-82.

Melnyk, V., E. van Herpen and H. C. M. van Trijp. 2010. 'The Influence of Social Norms in Consumer Decision Making: A Meta-Analysis.' Advances in Consumer Research 37: 463-464. Retrieved 3 July 2012 (http://www.acrwebsite.org/volumes/display. asp?id=15187).

Muthén, L. K. and B. O. Muthén. 2010. Mplus User's Guide. 6th ed. Los Angeles, CA: Muthén \& Muthén. Retrieved 3 July 2012 (http://www.statmodel.com/download/ usersguide/Mplus\%20Users\%20Guide\%20v6.pdf).

Nolan, J. M., P. W. Schultz, R. B. Cialdini, N. J. Goldstein and V. Griskevicius. 2008. 'Normative Social Influence Is Underdetected.' Personality and Social Psychology Bulletin 34 (7): 913-923.

Nordrehaug Astrøm, A. and J. Rise. 2001. 'Young Adult's Intention to Eat Healthy Food: Extending the Theory of Planned Behaviour.' Psychology \& Health 16 (2): 223.

OECD. 2011. Greening Household Behaviour. Paris: OECD Publishing.

Ogilvy. 2008. BIO—výzkumná zpráva. Prague: Ogilvy.

Povey, R., M. Conner, P. Sparks, R. James and R. Shepherd. 2000. 'The Theory of Planned Behaviour and Healthy Eating: Examining Additive and Moderating Effects of Social Influence Variables.' Psychology \& Health 14 (6): 991-1006.

Rettie, R., C. Barnham and K. Burchell. 2011. 'Social Normalisation and Consumer Behaviour: Using Marketing to Make Green Normal.' Kingston Business School Working Paper No. 8. Kingston upon Thames: Kingston Business School, Kingston University.

Rettie, R., K. Burchell and D. Riley. 2012. ‘Normalising Green Behaviours: A New Approach to Sustainability Marketing.' Journal of Marketing Management 29 (3-4): 420-444.

Rigdon, E. E. 1998. 'Structural Equation Modeling.' Pp. 251-294 in Modern Methods for Business Research, edited by G. A. Marcoulides. Mahwah, NJ: Lawrence Erlbaum Associates. 
Rivis, A. and P. Sheeran. 2003. 'Descriptive Norms as an Additional Predictor in the Theory of Planned Behaviour: A Meta-Analysis.' Current Psychology 22 (3): 218-233.

Rubin, D. 1974. 'Estimating Causal Effects of Treatments in Randomized and Non-randomized Studies.' Journal of Education Psychology 6 (5): 688-701.

Saba, A. and F. Messina. 2003. 'Attitudes towards Organic Foods and Risk/Benefit Perception Associated with Pesticides.' Food Quality and Preference 14 (8): 637-645.

Schreiber, J. B., A. Nora, F. K. Stage, E. A. Barlow and J. King. 2006. ‘Reporting Structural Equation Modeling and Confirmatory Factor Analysis Results: A Review.' The Journal of Educational Research 99 (6): 323-338.

Smith, J. R. and W. R. Louis. 2010. 'Do as We Say and as We Do: The Interplay of Descriptive and Injunctive Group Norms in the Attitude-Behaviour Relationship.' British Journal of Social Psychology 47 (4): 647-666.

Sparks, P. and R. Shepherd. 1992. 'Self-Identity and the Theory of Planned Behavior: Assesing the Role of Identification with "Green Consumerism".' Social Psychology Quarterly 55 (4): 388-399.

Staats, H. 2003. 'Understanding Proenvironmental Attitudes and Behavior: An Analysis and Review of Research Based on the Theory of Planned Behavior.' Pp. 171-201 in Psychological Theories for Environmental Issues, edited by M. Bonnes, T. Lee and M. Bonaiuto. Aldershot: Ashgate.

Synergy Marketing \& GfK. 2006. Potenciál BIO potravin na českém trhu: Marketingová studie (prezentace pro MZ $\breve{C} R$ ). (The Potential of Organic Food in the Czech Market: a Marketing Study (a Presentation for the Czech Ministry of Agriculture) Prague: Ministerstvo zemědělství ČR.

Tanaka, J. S. 1987. "'How Big Is Big Enough?": Sample Size and Goodness of Fit in Structural Equation Models with Latent Variables.' Child Development 58 (1): 134-146.

Tarkiainen, A. and S. Sundqvist. 2005. 'Subjective Norms, Attitudes and Intentions of Finnish Consumers in Buying Organic Food.' British Food Journal 107 (11): 808-822.

Terry, D. J. and J. E. O’Leary. 1995. 'The Theory of Planned Behaviour: The Effects of Perceived Behavioural Control and Self-efficacy.' The British Journal of Social Psychology / the British Psychological Society 34 (Pt 2): 199-220.

Thøgersen, J. 2006. 'Norms for Environmentally Responsible Behaviour: An Extended Taxonomy.' Journal of Environmental Psychology 26 (4): 247-261.

Thøgersen, J. 2009. 'Consumer Decision-Making with Regard to Organic Food Products.' Pp. 173-192 in Traditional Food Production and Rural Sustainable Development: A European Challenge, edited by T. de Noronha Vaz, P. Nijkamp and J.-L. Rastoin. Farnham: Ashgate Publishing.

Thøgersen, J. and F. Ölander. 2006. 'The Dynamic Interaction of Personal Norms and Environment-Friendly Buying Behavior: A Panel Study.' Journal of Applied Social Psychology 36 (7): 1758-1780.

Tukker, A., G. Huppes, J. Guinée, R. Heijungs, A. de Koning, L. van Oers, S. Suh, T. Geerken, M. van Holderbeke, B. Jansen and P. Nielsen. 2006. Environmental Impacts of Products (EIPRO): Analysis of the Life Cycle Environmental Impacts Related to the Final Consumption of the EU-25. Technical Report Series. Brussels: European Commission, Directorate-General, Joint Research Center.

Tuu, H. H., S. O. Olsen, D. T. Thao and N. T. K. Anh. 2008. 'The Role of Norms in Explaining Attitudes, Intention and Consumption of a Common Food (Fish) in Vietnam.' Appetite 51 (3): 546-551.

Urban, J. and M. Ščasný. 2007. 'Willingness-to-Pay for Organic Food and Its Determinants.' Pp. 504-513 in Proceedings of the 3rd International Conference EA-SDI 
2007, edited by E. Ritchelová and E. Sidorov. Ústí nad Labem: Jan Evangelista Purkyně University.

Urban, J., M. Ščasný and I. Zvěřinová. 2008. 'How Much Are Prague Consumers Willing to Pay for Organic Food?' Pp. 86-104 in Environmental Economics and Policy: Young Scholars Perspective, edited by P. Šauer. Litomysl: Litomysl Seminar Publishing.

Urban, J., I. Zvěřinová and A. Proková. 2010. ‘Motivation towards Energy-Saving Behavior among Students: An Application of the Theory of Planned Behavior.' Pp. 191-200 in Towards a Green Economy: Young Researcher Perspective, edited by J. Hlaváček, P. Šauer and J. Šauerová. Litomysl: Litomysl Seminar Publishing.

Václavík, T. 2009. Český trh s biopotravinami 2009. (The Czech Market in Organic Food) Moravské Knínice: Green marketing.

Villasenor Alva, J. A. and E. G. Estrada. 2009. 'A Generalization of Shapiro-Wilk's Test for Multivariate Normality.' Communications in Statistics - Theory and Methods 38 (11): 1870-1883.

West, S. G., J. F. Finch and P. J. Curran. 1995. 'Structural Equation Models with Nonnormal Variables.' Pp. 56-75 in Structural Equation Modeling: Concepts, Issues, and Applications, edited by R. H. Hoyle. London: Sage.

Zvěřinová, I. 2011. 'Faktory vysvětlující spotřební chování: Výzkum spotřebitelů biopotravin na vzorku obyvatel hl. m. Prahy a okresu Znojmo.' (Factors Explaining Consumer Behaviour: A Study of Organic Food Consumers on a Sample Population from Prague and the Znojmo District) Dissertation, Charles University, Prague.

Živělová, I. 2005. 'Current Situation of Demand for Organic Products in the Czech Republic.' Agricultural Economics—Czech 51 (7): 304-308.

Živělová, I. 2006. 'Faktory ovlivňující poptávku po biopotravinách.' (Factors Influencing the Demand for Organic Food) Pp. 401-405 in Zborník príspevkov z medzinárodnej vedeckej konferencie Medzinárodné vedecké dni 2006. Conference proceedings. Nitra: Slovenská pol'nohospodárska univerzita v Nitre.

Živělová, I. and J. Jánský. 2006. 'The Possibilities of Organic Food Market's Development in the Czech Republic.' Agricultural Economics—Czech 52 (7): 321-327.

Živělová, I. and J. Jánský. 'Faktory ovlivňující zájem spotřebitelů o biopotraviny.' Pp. 5-7 in Sborník př́íspěvků z mezinárodní vědecké konference Ekologické zemědělství. Retrieved 3 July 2012 (http://organicfarming.agrobiology.eu/ organicfarming/proceedings_pdf/03_zivelova_s5-7.pdf.).

Živělová, I. and J. Jánský. 2007b. 'The Conditions of Organic Market Development.' Agricultural Economics—Czech 53 (9): 403-410. 